\title{
The first cyborg and First World War bodies as anti-war propaganda
}

Article

Accepted Version

Macdonald, K. (2016) The first cyborg and First World War bodies as anti-war propaganda. Journal of War and Culture Studies, 9 (4). pp. 348-366. ISSN 1752-6272 doi:

https://doi.org/10.1080/17526272.2016.1185276 Available at https://centaur.reading.ac.uk/68964/

It is advisable to refer to the publisher's version if you intend to cite from the work. See Guidance on citing.

Published version at: http://www.tandfonline.com/doi/abs/10.1080/17526272.2016.1185276

To link to this article DOI: http://dx.doi.org/10.1080/17526272.2016.1185276

Publisher: Taylor \& Francis

All outputs in CentAUR are protected by Intellectual Property Rights law, including copyright law. Copyright and IPR is retained by the creators or other copyright holders. Terms and conditions for use of this material are defined in the End User Agreement.

\section{www.reading.ac.uk/centaur}

\section{CentAUR}

Central Archive at the University of Reading

Reading's research outputs online 
The first cyborg and First World War bodies as anti-war propaganda

Kate Macdonald

\begin{abstract}
This article discusses a play published in The Strand Magazine during the First World War which features a cyborg presenting anti-war and pacifist messages, used by The Strand to create anti-German propaganda. The article draws on theories of disability, cyborgs and the posthuman, and from new research on wartime fiction magazines. The importance of the cyborg character, Soldier 241, for the literary history of science fiction is explored by focusing on the relations between the mechanical and the impaired body, and on the First World War as a nexus for technological, surgical and military development. As a cyborg, this character reflects politicized desires that the wartime authorities did not acknowledge: a longing for the end of war, and refusal to countenance a society that rejected the impaired body.
\end{abstract}

\title{
Key words
}

Cyborg, First World War, disability, propaganda, pacifism, posthuman.

\section{Introduction}

In October 1917 The Strand Magazine published a one-act play by Perley Poore Sheehan and Robert H Davis, called 'Blood and Iron'. This text has been available for almost a hundred years, is listed online in at least three bibliographic sites, and has been digitized as part of a larger project (Hanley 2012; Clute 2015; Utter 2015; Conrad First). However, it has not been recognized until now for its remarkable anti-war statements and contemporary concern for the disabled serviceman. Set during wartime, 'Blood and Iron' also has importance in the history of science fiction, due to its leading character Soldier 241, the first modern cyborg in anglophone fiction, anticipating Czech novelist Karel Čapek's invention of the robot by three years. This article discusses the contemporary context of this remarkable 
piece of wartime pacifist propaganda, drawing on theories of disability, cyborgs and the posthuman, and from new research on wartime fiction magazines. Unlike earlier discussions of the sociological and cultural meaning of the cyborg that use a gender paradigm (for example, Haraway, 1985; Hollinger, 2003; Poggi, 2009; Hemmings, 2014), I focus on the relations between the mechanical and the impaired body rather than with the gendered body, and on the First World War as a nexus for technological, surgical and military development.

Joanna Bourke's seminal study of the impact of the war on the male body, Dismembering the Male (1996), is an important contexualising work for this subject, since it discusses the disfigurement and mutilation of servicemen by war. It dominates contemporary analysis of how the war changed British society from a disability studies perspective, but, like most accounts of the intersection of literary responses to the war and the body, it does not examine the popular culture of the day. As a historical study it rightly focuses on 'servicemen's correspondence, diaries and memoirs' as the basis for its literary corpus, working in concert with 'professional-medical constructions' and film and art (Bourke, 1999: 28-29). The popular responses to war's effect on the male body in pulp fiction and in monthly fiction magazines were not in Bourke's remit, and, indeed, have only lately become noticed by other scholars (Paris 2000; Potter 2005; Hammond and Towheed eds 2007; Korte and Einhaus 2009; Stevenson 2013; King 2014; Potter 2015). The present article focuses on a specifically fictional response to mutilation by war, and the horror of war itself, presented to a mass readership in a highly literary form: the closet play, one dramatic act designed to be read rather than performed. The relationship of this play to historical fact, such as Bourke's research has set out, exists inasmuch as it drew on the experiences of contemporary warfare, but it is a fantasy, functioning as an anti-war parable.

By 1917 the readers of The Strand would have become familiar with servicemen returning from war with serious impairments. Soldier 241 responds to this increasingly visible proportion of non-normate ${ }^{1}$ bodies in the population. He is 'fifty per cent human, fifty per cent machine', and has enhanced physical capabilities, made using 'a million cripples' who are now 'transformed into a million fighting units' (Sheehan and Davis, 1917b: 360). He has artificial body parts, super-strength hands, telescope eyes, and gold-hardened teeth. In the text, he was written to restore war-impaired soldiers to complete fighting capability: 'From 
a shattered bleeding wreck of no value to humanity I have made him into an efficient man' (Sheehan and Davis, 1917b: 361).

This phrase immediately recalls Mary Shelley's Creature from Frankenstein (1818), but her Creature is completely human, albeit composed of many human parts. He has no mechanical or machine components, though his brain is clearly enhanced for learning and other cognitive skills. The mechanical apparatus built by Victor Frankenstein to create him, and the scientific knowledge he was using, are more directly relevant to Davis and Sheehan's play than the result of the experiments. However, the 1910 silent film Frankenstein by J Searle Dawley shows the construction of the Creature (in a cauldron) from body parts, which may, possibly, have been influential in the public understanding of the Creature. ${ }^{2}$ The popular awareness of what was already being called 'Frankenstein's Monster' when reading this issue The Strand is more important for discerning contemporary readers' responses to Soldier 241, than a good knowledge of Shelley's novel.

The appearance at this time of Soldier 241 in a mass-market fiction magazine represents a confluence of war-related literary questions. The first concerns the content of the text and its presence in this issue of The Strand. Following on from this, its publication is unusual within an industry under the censorship of the Defence of the Realm Acts, although The Strand emphasized an anti-German reading through its advertising, and illustrations by war artist Steven Spurrier (Figure 1). The Strand offered its readers multiple narratives that refracted the war into political, ethical and humanitarian concerns. This text expressed public fear of the science and technology being used for war. The underlying concern of the play with the lives, bodies and futures of war-impaired servicemen is striking, yet also in concert with much of the fiction featuring such men at this time.

There are important differences between cyborgs and robots, yet these terms are often confused. Robots, in the sense of automated mechanical devices designed for utility, have been known since Homer: the most well-known Homeric automaton appears in book 18 of the Iliad in the workshop of Hephaestus. ${ }^{3}$ A cyborg is a machine applied to nature. The 1970s television characters the Six Million Dollar Man Man and the Bionic Woman are actually cyborgs, not bionic, because they are humans who have been enhanced with artificial mechanisms to be stronger and faster and have other, greater, capabilities than those of a human. Donna Haraway's description of 'a hybrid of machine and organism, a 
creature of social reality as well as a creature of fiction' is a classic definition with which Soldier 241 can be linked directly, by its social concerns as well as its mechanical capabilities (Haraway, 1991: 149). The term 'cybernetic organism' was invented by the scientists Manfred Clynes and Nathan S Kline in 1960, bringing the term 'cyborg' into common usage in 1960 s Anglophone science fiction that was seeing other radical changes in its sociology, notably from feminism and environmentalism. These were not anticipated by Davis and Sheehan, since their focus was the relationship of human bodies to the machinery of war. Robert Hemmings gives the mechanical context for Soldier 241, pointing out that what he describes as First World War proto-cyborgs lack 'the systems' informatics to control and regulate the entity's response to its new environment' (Hemmings, 2014). The First World War tank is a proto-cyborg because it cannot think, whereas its contemporary Soldier 241 has full volition. This volition as a cyborg, rather than merely a machine under command, positions Soldier 241 within the posthuman debate, which Elana Gomel defines as being 'over the identities and values of what will come after human' (Gomel, 2011: 340).

\section{'Blood and Iron'}

The play opens with the formal demonstration of Soldier 241 by a Scientist to his Emperor. The 'stage notes' which function as the text's narrative voice tell the reader that the cyborg 'moves with the deliberation of an automaton' (Sheehan and Davis, 1917b: 359). This indicates an explicitly mechanized individual, no longer human, since for the Scientist and the Emperor he represents 'a million cripples transformed into a million fighting units'. The industrial and dehumanising intent in these lines is reinforced by the Scientist's description of the central manpower problem of the war: 'the keynote of efficiency is the elimination of waste. Our problem was to eliminate the waste represented by the wounded' (Sheehan and Davis, 1917b: 359-60). When the Scientist is questioned about the scale of this new military invention, he speaks of military capacity rather than human suffering: 'I estimate the restoration of five army corps now immobilized because of missing arms and legs, deafened ears and blinded eyes'. The details of which body parts are damaged or missing remind the audience that humans are being damaged. Further phrases like 'shattered bleeding wreck', 'the fragment of a soldier', and 'he would today be rotting on the field - a source of 
pestilence - a worthless thing' indicate clearly how emotive language is deployed in this play to repel the reader away from the Scientist's perspective (Sheehan and Davis, 1917b: 362). When the cyborg is required to speak, 'his speech is laboured' (Sheehan and Davis, 1917b: 359). Yet he is an intelligent, reasoning individual, and uses apposite Bible quotations to show the immorality of the Emperor's conduct of the war (Sheehan and Davis, 1917b: 363). Soldier 241 tells the Emperor that his wife is lonely due to the absence of her husband and sons at the war, and that his people are starving. In the final moments of this very short play, Soldier 241, describing himself as 'tortured', kills the Emperor with his enhanced capabilities, to stop the war and the creation of more cyborgs like himself (Sheehan and Davis, 1917b: 364).

Of the two authors of this play, nothing is known about Robert H Davis. The other, Perley Poore Sheehan (1875-1943), was a Californian journalist and newspaper editor who began publishing short stories in pulp and adventure magazines from 1911, and then moved into screenwriting for silent movies, also becoming a novelist. He had had a number of scripts produced before the publication of 'Blood and Iron', and his biggest success would be writing the screenplay for The Hunchback of Notre Dame, for the 1923 film with Lon Chaney Hanley 2012; Clute 2015; Utter 2015). There are clear connections between that film and 'Blood and Iron', indicating Sheehan's interest in the monstrous and the trope of ethical strength found in the misunderstood.

'Blood and Iron' was first published in the US fiction periodical McClure's Magazine in the August 1917 issue, under the title of 'Efficiency'. It had been announced in the July issue as 'Blood and Iron' (Advertisement, 1917), but since its appearance in McClure's was under a different title, it is possible to suggest a timeline of events. Sheehan and Davis probably sold the play to The Strand Magazine after (and probably because) it had been bought for US publication in McClure's, since a sale to one magazine would encourage acceptance by another selling in a different geographical market. The title of the play was undoubtedly changed for copyright purposes, but the texts of both are near-identical. It is not known if the play was ever performed, but 'Efficiency' was reprinted in 1917 by George Doran Co in the US as a chapbook, containing 'An Appreciation' by former US President Theodore Roosevelt, who was a strong advocate for the war (Figure 2). 
The timing of the public appearance of this text (we have no information on when it was written) must be linked to the entry of the United States of America into the war. Jonathan Arnold notes that 'on just one day, Tuesday 5 June 1917, 9,660,000 young men presented themselves for registration. On 20 July a national lottery was held to select from these registrants the first batch of 687,000 who would actually join the army' (Arnold, 2015: 99). 'Blood and Iron' was bought by McClure's at some time in June 1917. The willingness of both publishers to print this text at this time suggests that their assessment of the public mood and of The Strand editor's legal security, made it probable that this play would help to maintain or increase their sales.

\section{The Strand Magazine and the war}

Widening the focus of our scrutiny, we can explore how unusual 'Blood and Iron' was by first examining the other elements of that issue of The Strand, and then consider how the contents differed from, or were typical of, British magazine fiction published in 1917. There are fifteen items in this issue of The Strand: eight pieces of short fiction; three chatty, nonfiction features; and four puzzle or miscellany features. Four of the short stories are written by well-known authors of the day (Joseph Conrad, Barry Pain, F Britten Austen, and May Edginton), and the tone of the fiction ranges from the comic to the serious. Otherwise, in this issue the tone and message of 'Blood and Iron' stands out, for its highly unusual use of science fiction, for its anti-war message, and its challenge to authority in support of a moral good. Steven Spurrier's illustrations and The Strand's marketing also suggests that the propaganda potential of this story could also be applied to the British and US governments, which were also waging war, and also creating hundreds of war-impaired soldiers every day. Thus 'Blood and Iron' can be considered as reflecting a political zeitgeist.

British reading in the First World War was tightly controlled by legislation. The Defence of the Realm Acts (DORA) of August and November 1914 prevented the publication of anything diminishing morale in mass-market print. Samuel Hynes observes that 'DORA gave the State unlimited power to control the instruments of communication and the transmission of information' (Hynes, 1990: 79). 'Likely to cause disaffection' was the key phrase in the Act that could be applied to anything written or expressed. Cate Haste has shown that, under the influence of the Acts, the Press Bureau exercised censorship and distributed negative 
propaganda in Britain, suppressing information as well as propagating misleading or false information. It issued 700 sets of instructions to editors, and 'was asked to admonish individual editors for indiscreet publications as often as three times a week' (Haste, 1977: 30-31). Fiction magazines also had to avoid non-compliance with the Act, by paying close attention to the content and illustrations of the stories they published. In this case, it would seem that The Strand actively encouraged an anti-German presentation of this play - a common line to take - to avoid the possibility of the play's anti-war message being taken as causing 'disaffection'. In the British wartime periodicals market, of which fiction magazines constituted approximately one-fifth, titles were closing down every month, and in 1917 this process was accelerated by paper shortages (Macdonald, 2016a). The Strand's editor would not publish anything that might risk sales or the eye of the law.

The Strand could afford to do this: it was a market leader in its field, and had a reputation for innovation in its fiction. At this period there had been a noticeable increase in the numbers of stories published in fiction magazines that directly addressed the situation of the war-impaired serviceman. Figure 3 indicates the numbers of stories featuring impairment in civilian and military settings over time, published in the research corpus. ${ }^{4}$ 1916 is the peak of activity, but in 1917 representation of the war-impaired serviceman was relatively high. Thus 'Blood and Iron' reflects the zeitgeist in its subject matter, but its political content and direction need more examination.

The Strand commissioned the British war artist Steven Spurrier to illustrate the play with anti-German propaganda details. Spurrier, and the McClure's illustrator T D Skidmore, working a few weeks ahead of him, both directed the readers of both magazines to understand the anti-war message as being aimed at Kaiser Wilhelm, rather than at the British War Office or the newly-involved US government, by invoking the familiar image of the German Emperor. This is a deliberate departure from the text, which describes the Emperor's costume drawing from elaborate modern imperial costume as worn in several European courts, but makes no allusion to Kaiser Wilhelm's distinctive characteristics (his short stature, his moustaches, his impaired arm) which were well-known from contemporary wartime cartoons. In contrast, Spurrier's illustration (Figure 4) shows the moustachioed Emperor enthroned in a military cloak and feathered parade helmet, on a dais, under a canopy. It is very clear which European male royal this illustration suggests, 
since only the Kaiser wore a moustache with the distinctive turned-up Prussian ends. His cousins Tsar Nicholas and George V wore naval beards with less exuberant moustaches (Figure 5).

Spurrier's second illustration is placed on the final page of the play (Figure 6). This location enables the illustration to arrest the reading progress of the rapidly-flicking casual reader. Soldier 241 now stands over the fallen and distorted figure of the dishevelled Emperor. Is this a reference to overpowering of a monarchy by force? The first Russian Revolution of February 1917 had succeeded by the power of militias under the people's control. The text carries a clear warning to mighty powers who destroy their people through war, but the illustrations narrow the focus to blame the Kaiser alone.

\section{War-wounded servicemen}

The powerful message that emerges from 'Blood and Iron' is that the war-wounded serviceman was not 'useless', as asserted so scornfully by the Scientist. Sheehan and Davis employ the reader's expected antagonism towards this repellent character to produce an unexpectedly positive and didactic result. The reader instead feels strongly that there is more to be done for and with the men impaired by war. To call a war-damaged serviceman a 'shattered bleeding wreck', or 'the fragment of a soldier' is not only inhuman, but also unpatriotic (Sheehan and Davis, 1917b: 362), and so we see that the Scientist's rhetorical appeal to logos, or reason, produces a result generated by pathos, or emotion. This does much to counter any potential alarm that the anti-war message of the text would 'cause disaffection', since the imperative to praise and support wounded servicemen redirected the reader's attention from whether the war should continue - a controversially pacifist message - to what could be done for the men returning from war with serious permanent impairments.

The figure of the war-impaired servicemen is unexpectedly common in the popular print culture of the war, of which The Strand was part. Postcards, souvenir cards and greetings cards were frequently used media for the dissemination of popular images at this time, and many photographs, illustrations, fine art paintings and cartoons depicting the impaired serviceman's body were used as postcards. These contributed a portfolio of standardized 
images to the public understanding of war impairments that would otherwise have been restricted to personal experience, or from reading emotive accounts published in newspapers and magazines to solicit donations for war charities. Such visual images, which were largely presented without any particularising context or narrative, assigned heroic, positive qualities to returning servicemen who were adapting to permanent injury. The use of religious imagery added a religiously-based moral imperative to the message of a heroic sacrifice that deserved reward or compensation.

Adverts for wheelchairs also presented sanitized imagery, but in 'Blood and Iron', Soldier 241 has an artificial left leg, two artificial hands, an artificial right forearm and elbow, an artificial left eye converted into a telescope, an artificial left ear, and replacement gold teeth (Sheehan and Davis, 1917b: 359). Apart from the teeth, these impairments can be found in wartime fiction, represented here in Figure 7. This collates all the physical impairments found in the fiction studied in the research corpus, showing that the most frequently deployed impairments in fiction during the war were missing legs and arms. In 1918 Colonel Sir Robert Jones, Inspector of Military Orthopaedics for the Army Medical Service, would report that $50 \%$ of the surgical work done for servicemen was for limb damage or loss (Jones, 1918: 41). In 1917 Sheehan and Davis were reflecting medical fact as well as a cultural norm.

An additional social concern that is clearly manifested in the play is the direct connection between the serviceman's bodily impairment and his remasculinisation. The fiction in the research corpus also reflects this strongly, and, indeed, the woman given as a compensatory, remasculinizing reward to the returned and war-wounded soldier is the trope most often used across the corpus (Macdonald, 2016b; Macdonald, 2016c). Soldier 241 speaks of his wife and his sons, and performs an act of violence which reaffirms his competence as a soldier, confirming his mastery of his situation. He carries in his reconstituted body the loss of strength, loss of corporeal integrity and (presumably, though this is not addressed in the text) loss of masculine beauty. Yet he conquers, he protects and he rejects war as a solution.

The human spirit conflicts with the utilitarian use of technology in this play. They are seen as inimical: what underlies the fear and distrust of science in this text? Before the war, the most well-known novelist who wrote about science and its encroachment on the modern 
world was H G Wells. His The Island of Dr Moreau (1896) creates posthuman people and animals by surgery and cross-breeding, in what Elana Gomel calls 'a parable of mad science' (Gomel, 2011: 344). In 1903 Wells' influential short story 'The Land Ironclads' anticipates the tank. The main impact of Wells' imaginative invention of the 'ironclad' was its unstoppability. It was a defensive weapon as well as an aggressive one: impossible to harm or damage unless with the same weaponry, an articulation of an arms race that was already manifest before the First World War broke out.

As a writer who published sensational fiction Sheehan would have known Wells' work. It was a remarkable imaginative leap by Sheehan and Davis to consider how the human body could itself become a weapon, rather than relying on the weapons it carried. Yet there is something deeply repellent in the utilitarian thinking rehearsed in 'Blood and Iron' that posits a mechanized soldier made out of body parts, not least because of the damaged soldiers within the story who have been 'harvested', and abandoned, presumably dead. Was this thinking commonly encountered during the First World War? Or was it artistic hyperbole for the sake of the tale?

\section{Cyborg history}

I want to examine here what the history of the cyborg in fiction and in weaponization can tell us about popular conceptions of war-related disability in the First World War.

In 1579, the French surgeon Ambroise Paré created a design for replacement parts for the human body, pioneering the concepts of prosthetics and bionics (Geduld, 1978: 32), but his design resembles armour, and braces and protects, rather than adding strength or capability. E T A Hoffman's short story 'Automata' (1814) describes wholly mechanical figures moving by apparently supernatural means (Willis 2006: 30). As already noted, Mary Shelley's Creature in Frankenstein was completely human, albeit constructed of many human parts. Edgar Allen Poe's darkly comic story 'The Man Who Was Used Up' was published in 1839 , and is relevant for our purposes in tracing the possible genesis of Sheehan and Davis's Soldier 241 because he, like they, was a North American author. Like Soldier 241 , the eponymous character of the story is also six feet tall, but he is a military veteran who consists almost completely of prosthetics. 
His function in the narrative is deflationary, to create humour, as are the similarlyconstructed Mrs Skewton and Captain Cuttle in Dickens' Dombey and Son (1846-48). This is an important contrast with the tragic figure that modern cyborgs often are, and which Soldier 241 undoubtedly is. Another North American literary antecedent to Soldier 241 is the Tin Man of The Wonderful Wizard of Oz (1900). Technically he is a cyborg, since he is composed of human and metal parts, but there is nothing of the machine about him, nor are his capacities artificially enhanced: they are merely replaced. He is not a weapon of war, nor does he address the human condition in the politicized and laceratingly anguished way that Sheehan and Davis create for Soldier 241. The context of war was clearly crucial for this modern iteration of the cyborg.

After the First World War, two further plays brought the idea of machines and the human closer together. As I have already mentioned, Karl Čapek's RUR: Rossum's Universal Robots (1920) invented the word 'robot', and Ruggero Vasari's Angoscia delle Macchine [The Anguish of the Machines] (1923) 'exemplifies the growing ambivalence towards the machine that merged in the 1920s' (Poggi, 2009: 245). This appearance of a cyborg and two robots, in three plays, within six years of each other, emerging from the First World War, is a concatenation too closely connected with symbolic statements to be coincidence. The authors shared a need to prove their conceptions visually. The shock of the new (in Vasari's case a Futurist 'new') needed to be experienced to be believed.

Adam Roberts divides the science fiction of the early twentieth century into 'High' and 'Low' Modernist, and, following Maria DiBattista, between those authors and texts who were antimachine and those who reacted 'generally speaking, with excitement and exhilaration' to increasing technological change, for example in pulp science fiction (Roberts, 2005: 157). These divisions are impacted, as Roberts admits, by the major exception of the Futurists who embraced the machine, but the overwhelming message from the dystopias of early twentieth-century science fiction was that when 'an imagined future society has been ordered along technological or scientific lines [it is] to the detriment of the individual quality of life of that society's citizens' (Roberts, 2005: 159). This speaks directly to the message in 'Blood and Iron', which shows the appalling results of allowing science to dominate human needs. Sheehan's oeuvre is wholly within the pulp tradition, yet his 'Blood and Iron' is more thematically aligned with that of High Modernist science fiction. 
John Clute categorises cyborgs as 'elementary medical' (cf Poe and Dickens), 'functional' (Soldier 241) and 'adaptive' (Clute 2016). E V Odle's novel The Clockwork Man (1923), an example of the 'adaptive' cyborg, should be read in parallel with the plays, since its protagonist's clockwork mechanism is for personal use rather than to influence the external world. Early pulp science fiction focused on what Clute calls 'extreme medical cyborgs', but a decade later, the idea of the cyborg as a posthuman enhanced with mechanisms appeared in Olaf Stapledon's novel The Last and First Men (1930), which is usually held to be its first appearance in classic science fiction. C L Moore was the first to write about a female cyborg in 1944, in 'No woman born' (Baccolini 2000). Many subsequent novels, stories, TV episodes and films have featured cyborgs, classically epitomized in its military application by The Terminator in the eponymous 1984 film by James Cameron (although the Terminator character is, strictly speaking, an android). Imperator Furiosa in George Miller's film Mad Max: Fury Road (2015) is a strong example of a cyborg character in post-apocalypse science fiction: she wears a detachable prosthesis to replace a missing fore-arm, and is thus mechanised to regain function and also gain enhanced capability.

By positioning Soldier 241 in the lineage of fictional cyborgs, I am participating in what Steven Mentor calls 'a legitimizing move meant to simultaneously assert a slow evolution of techno-humans over time' (Mentor, 2011: 48). Soldier 241 is an important figure in science fiction, not just because he is, as I hope to establish here, the earliest true cyborg in anglophone fiction, but because he is a product of the impulse to posthumanism generated by the political, ethical and technological crucible of the First World War, truly the first war of modernity in all its horrible aspects. While it has been generally accepted that the Second World War produced the first major combination of mechanisation and cybernetics into a range of disciplines and movements, the evidence of Sheehan and Davis's Soldier 241 pulls the birth of the cyborg back to an earlier war (Hables Gray et al, 1995: 5).

Soldier 241 is the beginning of the fantastical creations that represent modern dreams of the human to be better, faster, stronger. It is highly significant that in the moment of this cyborg's birth in fiction it is designed to kill and does so, showing how killing can be achieved more efficiently. The undeniable emergence of the posthuman in this unique piece of literature embodies the postmodern condition. 
The replacement of external body parts with prosthetics, mechanical versions of eyes, hands and limbs, had refined itself into an art form by the time of the Renaissance. $\mathrm{N}$ Katherine Hayles considers that 'the posthuman cyborgian view' is a way of seeing 'the body as "the original prosthesis we all learn to manipulate, so that extending or replacing of [defective] body parts with other prosthetic devices [limbs, teeth, artificial implants, etc.] becomes the continuation of a process that began before we were born"' (Hayles, 1999: 3). If we consider the human body as being the raw material to be enhanced and improved, the cyborg becomes the human's natural state, unlike the imperfect weakness into which we are born. This assertion is ratified by influential thinkers about cyborg ontology. Chris Hables Gray et al state that:

cyborg technologies can be restorative; in that they replace lost functions and replace lost organs and limbs; they can be normalising, in that they restore some creature to indistinguishable normality; they can be ambiguously reconfiguring, creating posthuman creatures equal to but different from humans [...] and they can be enhancing, the aim of most military and industrial research. (Hables Gray et al,1995: 4)

In 'Blood and Iron' Soldier 241 combines the enhancement and the restorative functions, becoming an enhanced human being. It is important to note that Soldier 241's enhancement is not only in bodily strength and function, but in moral and ethical strength as well. Once again it seems important to ask, what was it about the culture of the First World War that could evolve the cyborg out of industrial-scale mechanized warfare?

\section{Cyborgs and posthumans}

Leading cyborg theoretician Jennifer Gonzalez says: 'The image of the cyborg has historically recurred at moments of radical social and historical change [...] imaginary representations of cyborgs take over when traditional bodies fail. In other words, when the current ontological model of human being does not fit a new paradigm, a hybrid model of existence is required to encompass a new, complex and contradictory lived experience. The cyborg body thus becomes the historical record of changes in human perception' (Gonzalez, 1995: 270). This is a new way of thinking about the cyborg in its historical moment. It encourages us to stop 
thinking of the cyborg as a machine that has somehow acquired humanity (what we might call the android model of cyborgian evolution), and to think instead of the cyborg as a surrogate human with enhanced agency who can be sent into fiction to enact new ideologies, narrative situations, and ethical dilemmas as a way of allowing the human experience to grow towards, and possibly into, being posthuman.

Elana Gomel notes that scientific development always requires 'a new conceptual map for ethical judgment. The contours of this map may be seen to emerge in works of science fiction (SF), which not only vividly dramatize the implications and consequences of new technologies and discoveries, but also exert a powerful influence on culture, creating a feedback loop of images and ideas' (Gomel ,2011: 339). Going back to my suggestion that 'Blood and Iron' is an anti-war parable we may consider it as a direct response not just to the appalling waste of human life and bodies in war, but also to the technologies that were proliferating to keep the war going. 'Blood and Iron' dramatizes the implications and consequences of new technologies and discoveries for the reader to feel the consequences in ethical human terms, quite separate from politics and military strategy.

We should ask, as Jennifer Gonzalez suggests, to what degree this cyborg can be read as a servant and toy, and to what degree it is an autonomous social agent (Gonzalez, 1995: 269). In the context of war it is legitimate to ask what side the cyborg should 'naturally' be on: on that of the humans, or that of the machines? Elana Gomel has observed that the state of 'posthumanity has arisen as a cultural response to the ideological, religious, and philosophical attempts to police the borders of humankind'. Perpetrators of genocide and ethnic cleansing, in the First and Second World Wars, both attempted to represent the victims as non-human. Gomel continues: 'cyborg is thus a social metaphor that represents the posthuman subject as polymorphous, fragmented, multiple, transcending the dichotomies of organic and inorganic, human and animal, male and female' (Gomel, 2011: 341).

While this theoretical approach is too generic for Soldier 241 - a weaponized human, with strong social impulses and moral authority - it seems clear that the metaphorical use of Soldier 241 is multivariate. He is a nightmare, a hope, the future, the present, and the past. As a cyborg he embraces all future possibilities. He holds up a moral standard to say 'thus far and no farther': he is the policeman holding up the stop sign. But is he the law? 
He is horribly possible for the readers of 1917. Darko Suvin describes Čapek's postwar readers as being faced with 'catastrophic forces of inhuman violence amid which they have to live, suffer, and die', a tension that characterizes the emergence of resistance or acceptance (Suvin, 1979: 271). Istvan Csicsery-Ronay Jr notes that Donna Haraway's study of cyborgs 'is obliquely modelled on the proletariat and on women under patriarchy', which reiterates the cyborg as a representative of the oppressed (Csicsery-Ronay, 2003: 122). Veronica Hollinger considers this point from a feminist studies perspective by showing how the figure of the alien explores issues of difference, citing Haraway's conclusion that cyborgs in science fiction make the status of human very problematic (Hollinger, 2003: 133). These are challenging ideas, inconceivable in the culture of 1917. But by presenting a cyborg as a possible future, which readers could readily accept, given the remarkable leaps forward in science demanded by the technological requirements of the war machine, in both surgery and weaponry, this small and unobserved piece of propagandist entertainment from 1917 gives its readers the example of a super-enhanced military weapon who can also feel empathy and refuse to allow more slaughter.

He has been made into what the Scientist calls 'an efficient man' (Sheehan and Davis, 1917b: 362), displaying more humanity than his creators because he is humanity, made of the war-impaired bodies of men who could do no more. He reflects a political zeitgeist that the authorities did not want to acknowledge (for whose suppression the Defence of the Realm Act was first passed in August 1914). As for his representation of the war-disabled servicemen, it may not be too radical to suggest that in his wholeness, and his resolution to prevent war's continuation, he embodies what they might have felt and wanted, and might also have wanted the masses of magazine fiction readers to also want: to end war now. He records a change in human perception, and an acknowledgement of anti-war impulses in wartime. Using Haraway's description arrived at some seventy years after its creation, the cyborg in 'Blood and Iron' is 'a fiction mapping our social and bodily reality [...] the illegitimate offspring of militarism and patriarchal capitalism' (Haraway 1991, 150), and as such, when he appears, he should be given attention. 
The research from which this article is drawn was supported by a Visiting Research Fellowship at the Department of Digital Humanities, King's College London, in the CENDARI (Collaborative European Digital Archive Infrastructure) project funded by the European Commission FP7 for Research (2013); and by the award of the Sassoon Visiting Research Fellowship at The Bodleian Library, University of Oxford (2014). Additional thanks are due to Dr David Marsh for data visualisation; to Dr Patrick Belk and Professor Elizabeth Amann for their help in acquiring images; to the Panter \& Hall Gallery, London, for their assistance with tracing the artist's estate; and to Nick Spurrier for kindly granting permission for the use of the illustrations by Steven Spurrier. An early version of this essay was presented at the conference First World War Popular Culture at the University of Chester, 2-3 July 2015; and was published as a feature article in History Today 66:5 (May 2016), 31-36.

Figure captions

Figure 1: Cover of October 1917 issue of The Strand Magazine. Notice that although the play does not mention the Kaiser, the advertising on this cover does.

Figure 2: Cover of the chapbook edition of Efficiency by Dais and Sheehan. The cover illustration bears no relation whatsoever to its contents, suggesting a rushed printing.

Figure 3: Graph depicting the numbers of short stories published in five fiction magazines throughout the war, that explicitly featured characters with impairments, divided into stories with civilian (red) and military (green) settings.

Figure 4: Illustration by Steven Spurrier from 'Blood and Iron' (reproduced by permission).

Figure 5: The three Emperors of the First World War: Tsar Nicholas II, Emperor and Autocrat of all the Russias; King George V of the United Kingdom and the British Dominions and Emperor of Indian, and Kaiser Wilhelm II, the German Emperor and King of Prussia.

Figure 6: Illustration by Steven Spurrier from ‘Blood and Iron' (reproduced by permission). Figure 7: Graph of data collected from five magazines published throughout the war that explicitly featured characters with impairments, showing the range and frequency of physical wounds featured in the stories. 
Works Cited

Advertisement, 1917. McClure's Magazine, 49 (July), pp. 54.

Arnold, J. 2015. "Please send me Tess of the DR. Rbyvilles (Harding)": The reading preferences of American soldiers during the First World War. In: S Towheed and E G C King (eds). Reading and the First World War. Readers, Texts, Archives. Basingstoke: Palgrave Macmillan, pp. 99-115.

Baccolini, R, 2000. In-between subjects: C L Moore's “No Woman Born”. In: K Sayer and J Moore (eds). Science Fiction: Critical Frontiers. Basingstoke: Macmillan, pp. 140-153.

Bourke, J, 1999 (1996). Dismembering the Male. Men's Bodies, Britain and the Great War. London: Reaktion Books.

Clute, J, 2015. Perley Poore Sheehan. In: The Encyclopaedia of Science Fiction. Accessed 27 April 2016. Available at < http://www.sf-encyclopedia.com/entry/sheehan perley poore $>$. Clute, J, 2016. Cyborgs. In: The Encyclopaedia of Science Fiction. Accessed 27 April 2016. Available at < http://www.sf-encyclopedia.com/entry/cyborgs $>$.

ConradFirst. The Joseph Conrad Periodical Archive. Accessed 18 November 2015. Available at $\langle$ http://www.conradfirst.net/view/image?id=18453 $>$.

Csicsery-Ronay Jr, I, 2003. Marxist theory and science fiction. In: E James and F Mendlesohn (eds). The Cambridge Companion to Science Fiction. Cambridge: Cambridge University Press, pp. 113-124.

Garland Thomson, Rosemarie. Extraordinary Bodies. Figuring Physical Disability in American Culture and Literature. New York, Columbia University Press.

Geduld, H M, 1978. Genesis II: The evolution of synthetic man. In: H M Geduld and R Gottesman (eds). Robots Robots Robots. Boston: New York Graphic Society, pp. 3-37. Gomel, E, 2011. Science (fiction) and posthuman ethics: Redefining the human. The European Legacy: Toward New Paradigms, 16:3, pp. 339-354.

Gonzalez, J, 1995. Envisioning cyborg bodies. Notes from current research. In: C Hables Gray (ed.). The Cyborg Handbook. London: Routledge, pp. 267-79. 
Hables Gray, C, Mentor, S, Figueroa-Sarrieria, H J, 1995. Cyborgology. Constructing the knowledge of cybernetic organisms. Introduction. In: C Hables Gray (ed.). The Cyborg Handbook. London: Routledge, pp. 1-14.

Hammond M and Towheed S (eds), 2007. Publishing in the First World War. Essays in Book History. Basingstoke: Palgrave Macmillan.

Hanley,T, 2012. Perley Poore Sheehan, 1875-1943. In: Tellers of Weird Tales. Accessed 23 October 2015. Available at <http://tellersofweirdtales.blogspot.be/2012/12/perley-pooresheehan-1875-1943.html>.

Haraway, D J, 1991. A cyborg manifesto: Science, technology, and socialist-feminism in the late twentieth century (1985). In: Simians, Cyborgs, and Women. The Reinvention of Nature. London: Free Association Books, pp. 149-182.

Haste, C, 1977. Keep the Home Fires Burning. Propaganda in the First World War. London: Penguin Books.

Hayles, N K, 1999. How We Became Posthuman: Virtual Bodies in Cybernetics, Literature, and Informatics. Chicago: University of Chicago Press.

Hemmings, R, 2014. Proto-cyborgs in war-time: The tank, the drill and the motor-chair. The Space Between. Literature and Culture 1914-1945 10. Accessed 12 November 2015.

Available at <http://www.spacebetweenjournal.org/>

Hollinger, V, 1990. Feminist theory and science fiction. In: E James and F Mendlesohn (eds). The Cambridge Companion to Science Fiction. Cambridge: Cambridge University Press, pp. 125-136.

Hynes, S, 1990. A War Imagined. The First World War and English Culture. London: The Bodley Head.

Jones, R, 1918. An Address on the Orthopaedic Outlook in Military Surgery. The British Medical Journal, 12 January, 41-45.

Korte B and Einhaus A-M, 2009. 'Short-term memories: The First World War in British short stories, 191439', Literature \& History 18:1, 54-67. 
Macdonald, K, 2016a. Popular periodicals: Wartime newspapers, magazines and journals. In: A-M Einhaus and K Baxter (eds). The Edinburgh Companion to the First World War and the Arts. Edinburgh: Edinburgh University Press, forthcoming.

Macdonald, K, 2016b. The woman's body and the disabled ex-serviceman in the First World War. In: C Ehland and C Wächter (eds). Middlebrow and Gender: 1890-1945. Leiden: Brill, 60-78.

Macdonald, K, 2016c. The woman's body as compensation for the disabled First World War soldier. Journal of Literary and Cultural Disability Studies 10:1 (2016) 53-70.

Mentor, S, 2011. The coming of the Mundane Cyborg. Revista Teknokultura 8:1, 47-61.

Paris M, 2000. Warrior Nation: Images of War in British Popular Culture, 1850-2000. London: Reaktion Books.

Poggi, C, 2009. Inventing Futurism. The Art and Politics of Artificial Optimism. Princeton: Princeton University Press.

Potter, J, 2005. Boys in Khaki, Girls in Print: Women's Literary Responses to the Great War, 1914-1918. Oxford: Oxford University Press.

Potter J, 2015. "'Khaki and kisses": Reading the romance novel in the Great War'. In Towheed S and King E C G (eds), Reading and the First World War: Readers, Texts: Archives. Basingstoke: Palgrave Macmillan, 29-44.

Roberts, A, 2005. The History of Science Fiction. Basingstoke: Palgrave Macmillan.

Sheehan, P P, and Davis, R H, 1917a. Efficiency. A Play in One Act. McClure's Magazine 49 (August), 33, 56-58.

Sheehan, P P, and Davis, R H, 1917b. Blood and Iron. The Strand Magazine 54: 322 (October), 359-65.

Stevenson R, 2013. Literature and the Great War 1914-1918. Oxford: Oxford University Press.

Suvin, D, 1979. Metamorphoses of Science Fiction. On the Poetics and History of a Literary Genre. New York and New Haven: Yale University Press. 
Utter, V S, 2015. Sheehan, Perley Poore. The SF Encyclopaedia. Accessed 12 November 2015. Available at <http://www.sf-encyclopedia.com/entry/sheehan perley poore>.

Willis, M, 2006. Mesmerists, Monsters and Machines. Science Fiction and The Cultures of Science in the Nineteenth Century. Kent OH: Kent State University Press.

\footnotetext{
${ }^{1}$ The term 'normate' was coined by disability studies theorist Rosemarie Garland Thomson as a way of identifying 'the constructed identity of those who, by way of the bodily configurations and cultural capital they assume, can step into a position of authority and wield the power it grants them' (Garland Thomson 8).

2 The film has been restored by the British Film Institute and can be seen at http://www.bfi.org.uk/news-opinion/news-bfi/lists/10-great-silent-horror-films (accessed 27 April 2016).

${ }^{3}$ These are wheeled tripods designed to go of their own accord to the assemblies of the gods and return again.

${ }^{4}$ These periodicals were Nash's Pall Mall Magazine, The Story-Teller, The Grand Magazine, Cassell's Magazine, and The Strand Magazine. Around 4000 stories were read, published between July 1914 and December 1918, producing a corpus of 181 stories that explicitly use or engage with impairment.
} 